\title{
原著
}

\section{皮下埋め込み式リザーバーを用いた腹腔洗浄細胞診による 卵巣癌の術後管理}

\author{
香川医科大学母子科学教室 ${ }^{1)}$, 香川県立がん検診センター婦人科 ${ }^{2)}$ \\ 大野 正文 ${ }^{1)}$ 五十嵐達也 ${ }^{1)}$ 塩田 敦子2) 黒瀬 高明1) \\ 半藤 保 ${ }^{1)}$
}

卵巣癌術後の再発を早期に発見する目的で, 初回手術後定期的に施行した腹腔洗浄細胞診によ り, CT, MRI, USG などの各種画像診断法や, 各種血清腫湯マーカー值が陽性所見を示す前に, 細胞診断学的にとらえることのできた 2 症例を報告した. 腹腔洗浄細胞診は, 術後腹腔内化学療法 を施行するために設置した皮下埋め込み式りザーバーを介して行ったもので，リザーバーが卵巣癌 術後管理の細胞採取経路としても有用であることを示した。このような方法で得られた細胞標本の 採取細胞量は十分あり, 細胞学的鑑別診断は比較的容易と判断された。

Key words : Ovarian cancer-Peritoneal cytology_- Subcutaneously implanted Infuse-A -Port-Recurrence-Early detection

\section{I. はじめに}

卵巣癌は腹腔内播種を容易にきたす予後不良な悪性 腫瘍で，その術後管理上，再発の早期発見は重要であ る. そのための手段は内外診に加え，第 1 にCT, MRI, USG などの画像診断法と第 2 に各種血清腫場 マーカーが臨床上有用であり広く応用されている，腹 腔鏡による術後管理は症例によりきわめて高い価値を 有するが，その侵襲性のためにまだ広く普及するにい

\footnotetext{
A new follow up method for ovarian cancer using serial peritoneal washing cytology from a subcutaneously implanted Infuse-A-Port

Msayuki OHNO ${ }^{1)}$, M.D., Tatsuya IGARASHI'), M.D., Atsuko SHIOTA ${ }^{2)}$, M.D., Takaaki KUROSE ${ }^{1)}$, M.D., Tamotsu HANDO $^{1)}$, M.D., F.I.A.C.

${ }^{11}$ Department of Perinato-Gynecology, Kagawa Medical School

${ }^{2)}$ Kagawa Prefectural Cancer Detection Center

論文別刷請求先：⑦61-07 香川県木出郡三木町池戸 1750 の

1 香川医科大学母子科学教室 大野正文

平成 5 年 7 月 30 日受付

平成 5 年 9 月 3 日受理
}

たっていない. 腹水あるいは culdocentesis による腹 腔細胞診は, 卵巣癌の術前診断に際し補助診断法とし てしばしば用いられてきたが, 卵巣癌の術後管理にお いては，これまで細胞採取が困難なこともあってその 応用は多量の腹水貯留を示す症例に限られてきた。し かしながら皮下埋め込み式りザーバー（以下リザーバ 一）方卵巣癌術後の腹腔内化学療法に応用されるよう になってから ${ }^{11}$,このリザーバーを通して腹水あるい は腹腔洗浄液を採取できるようになり，これを細胞診 断に応用する第 3 の非侵襲的方法が可能となった。わ れわれは腹腔洗浄細胞診が画像診断や腫湯マーカーに よる診断法に先んじて, 卵巣癌再発の早期発見に役立 つた 2 症例を経験し, 腹腔洗浄細胞診による卵巣癌の 術後管理について検討したので報告する.

\section{II. 対象と方法}

対象は手術時にリザーバーを腹腔皮下に設置し，反 復して腹腔洗浄細胞診あるいは腹水細胞診を施行され た卵巣癌患者 7 例で，その一覧を表 1 に示した。臨床 進行期はいずれも I c 期以上の腹腔内に悪性細胞の播 
表 1 卵巣癌管理に抢ける腹腔洗浄細胞診症例一筧

\begin{tabular}{|c|c|c|c|c|c|c|c|c|}
\hline case & age & stage & histological diag & ascites & image diag ${ }^{1}$ & tumr marker & peritoneal cytology & compatibility $^{2}$ \\
\hline 1. S.K. & 49 & IV & mucinous adenoca & - & $\mathrm{NED}^{3}$ & negative & negative & Yes \\
\hline 2. K.Y. & 38 & I c & serous pap. adenoca & - & NED & negative & negative & Yes \\
\hline 3. M.M. & 60 & IIIC & serous cystadenoca & + & cancer & positive & positive & Yes \\
\hline 4. K.M. & 57 & I c & serous cystadenoca & - & NED & negative & positive & No \\
\hline 5. K.F. & 56 & III c & serous pap. adenoca & + & cancer & positive & positive & Yes \\
\hline 6. K.I. & 16 & I c & mucinous cystadenoca & - & cancer & positive & positive & Yes \\
\hline 7. R.M. & 37 & II c & serous pap. adenoca & - & NED & negative & positive & No \\
\hline
\end{tabular}

1. findings by CT, MRI, USG, 2. compatibility of clinical findings and peritoneal cytolygy, 3. no evidence of disease

種を認める症例で，組織診断は 5 例が漿液性囊胞腺 癌，2 例が粘液性囊胞腺癌であった。リザーバー設置 後の臨床経過中に腹水を認めた症例が 2 例（症例 3 お よび 5 )，認めなかった症例が5例であった。画像診 断としてCT, MRI, USG が施行され，癌の再発ま たは再燃と診断すべき腫瘍が 3 例に描出された。腫瘍 マーカー注初回手術前に異常高值を示し，治療後化一 旦下降した後, 再上昇を示す場合を再発の指標とし た。腹腔細胞診の材料には，腹水の貯留を認めない症 例では生食液を用いた腹腔洗浄液を供した。

採取方法は腹水の貯留を認女る症例では経皮的に $21 \mathrm{G}$ の翼状針でリザーバーを穿刺し，20 mlのシリ ンジにてゆっくり吸引採取し, 腹水の貯留を認めない 症例では穿刺針より $200 \sim 500 \mathrm{~m} l$ の生食液を $20 \mathrm{ml}$ のシリンジで加圧注入することで生ずる水流によって 洗浄した後，ゆっくり吸引採取した。採取時期は化学 療法剤の腹腔内投与時に施行し, 十分量の洗浄液を採 取した後に薬剤を投与した。

\section{III. 結果}

表 1 に示すように，理学的所見に加之，臨床的再発 徵候としての腹水の貯留, 画像診断による再発所見の 有無, 腫瘍マーカーの再上昇の有無を総合的治判断し て，再発なしと診断すべき症例は 4 例であった。その 4 例中，腹腔洗浄細胞晾が陰性のものは2例で，陽性 が 2 例（症例 4 扔よび 7 ）認められた。臨床上，再発 ありと判断された 3 例（症例 $3 ， 5$ および 6 ）は，す べて細胞診が陽性であった。したがって，臨床所見と 細胞診との一致は 7 例中 5 例で，不一致は 2 例（症例 4 抢よび 7 ) に認められた。この不一致の症例 4 は腹 腔洗浄細胞診の再検查で陽性であったため手術を施行 し, 大網, 腸間膜に直径 $2 \mathrm{~cm}$ 以下の播種性腫瘍が認 められ，組織学的にも卵巣癌の再発が確認された。こ

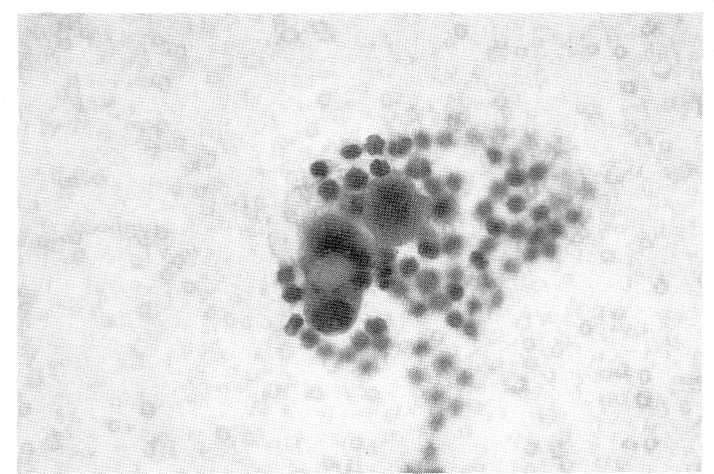

写真 1 洗浄細胞診. 中皮細胞に囲まれた癌細胞を認める (Pap. 染色， ×200)

の症例を以下に報告する。

症 例

初回治療開始時の年歯は 57 歳で, 臨床進行期は I $\mathrm{c}$ 期, 組織骖断は獎液性囊胞腺癌であった。平成 4 年 5 月 19 日に両側付属器切除，骨盤りンパ節廓清術お よびリザーバー設置術を施行した。子宮はすでに子宮 筋腫にて摘出されており，完全手術例であった。手術 時にダグラス窩より採取した洗浄細胞診で悪性細胞を 認めた (写真 1 )。手術後りザーバーよりカルボプラ チン（以下 $\mathrm{CBDCA}$ ) を腹腔内投与した。術前の血清 CA 125 は $72 \mathrm{U} / \mathrm{m} l$ であったが, 術後の化学療法を2 コース施行後に正常值に下降し，再上昇を認めなかっ た。腹腔洗浄細胞診 (平成 4 年 6 月) は $\mathrm{CBDCA}$ 投 与による変性を認め(写真 2$) ， 8$ 月および 9 月には 陰性となった。外来化学療法の通院時にリザーバー直 上の皮膚を穿刺して生食液で洗浄細胞診を施行した。 平成 5 年 1 月 class IV, 平成 5 年 5 月 class $V$ (写真 3 ) となり, 平成 5 年 6 月施行の腹腔洗浄細胞診でも class $V$ であった。平成 5 年 6 月再開腹術を施行した。 再開腹時，腹水を認姑大網に直径 $0.5 \sim 2.0 \mathrm{~cm}$ の 腫瘤を数個，回盲部の腸間膜に直径 $2 \mathrm{~cm}$ の腫瘤を 1 


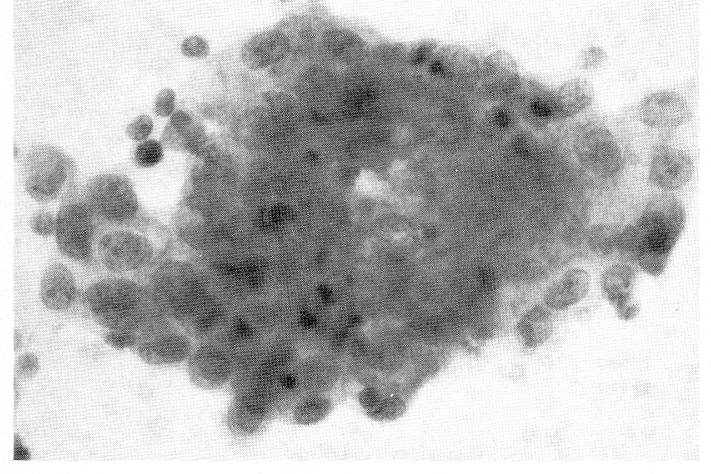

写真 2 洗浄細胞診. 抗癌剂に上る癌細胞の変性傾向を認め る(Pap. 染色, ×200)

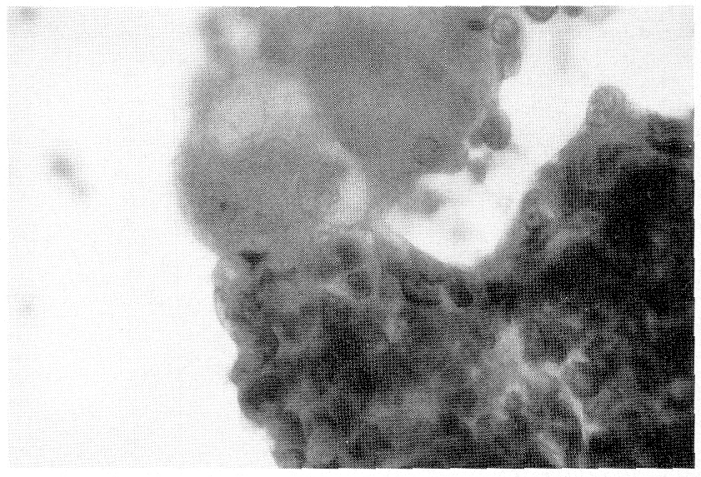

写真 3 洗浄細胞診. 腺構造を示す癌細胞集塊を認める (Pap. 染色, ×200)

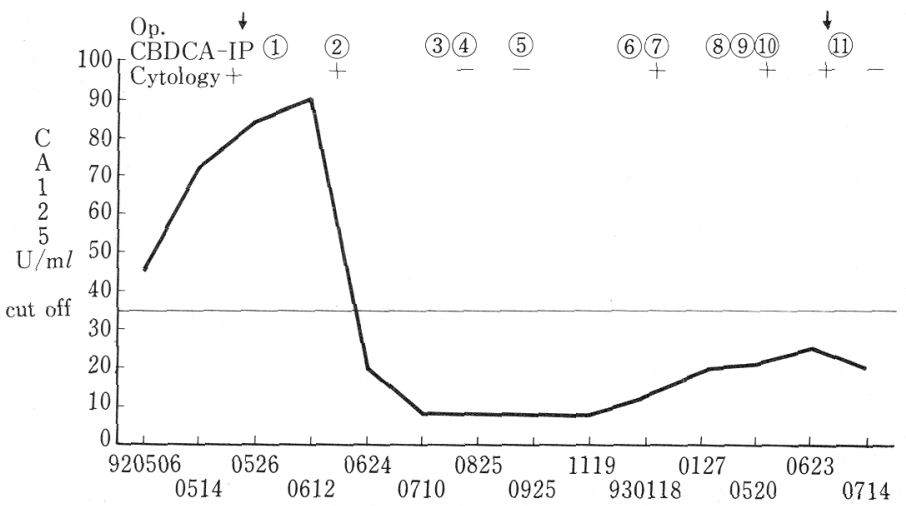

図 1 臨床経過 (case 4)
個認めた。そのため大網切除術, 腫嚎摘出術を施行し た. 組織学的に卵巣癌の転移病巣々診断された。本症 例の臨床経過を図 1 に示した。

\section{IV. 考察}

一般的に卵巣癌は，症状がでにくいこともあって， 手術摘出材料に対与る病理組織学的確認の行われる数 カ月～数年前に腹腔内に癌細胞を剥離，落下している ことが多く, 腹腔細胞診あるいは経卵管性に移動する 癌細胞を子宮頸胵部細胞診で拾いあげ，確認すること ができる ${ }^{2)}$. 事実，古くから腹腔への直接的アクセ久 経路としての culdocentesis が行われ，細胞診による 早期, 無症候性の卵栄癌検診が試みられた 子宮癌検診を目的とした細胞診で, 卵巣癌発見の端緒 をなしたという報告も散見される。しかし，これらの 方法を日常臨床に応用するには, その手技の困難さ, 感度などが卵巣癌検診に向かないこと，不適標本が多
いこと，発見される卵巣癌は必ずしも目的とする早 期, 無症候性のものでないことなどのため, 細胞診に よる卵栄癌の診断法は広く普及するにいたらなかっ た。

しかしながら，今回，われわれが示したように腹壁 皮下に設置したリザーバーを穿刺し，生食液を注入し て得られる洗浄細胞診は, 定期的に反復して実施する ことで卵采癌術後の管理, 特に再発の早期発見上, 量 的, 質的に適当な標本を得ることができる簡便な方法 である.リザーバーは本来卵巣癌化学療法の腹腔内投 与ルートとして考案されたものであるが, 腹水の吸引 排液はもとより, 本稿で示すように腹腔洗浄細胞㟝に 上る卵栄癌再発の早期発見に, もっと応用されてよい といえよう.さらに, 化学療法の効果を腫湯細胞の変 性の有無を細胞誩断学的に評価することで使用薬剤の 抗癌効果判定にも応用しうると判断された。実際, 抗 癌剂の効果により写真 2 亿示したように腫瘍細胞は変 性し，vividな腫瘍細胞を認めなかった。 
腹腔細胞診はときに不満足な標本や偽陰性の成績を もたらすことがあるので，細胞診標本作成に当たって は十分注意する必要がある ${ }^{5}$. 腹腔液吸引前に, 体位 変換により腫瘍細胞を浮遊しやすくすること，洗浄液 注入後直ちに吸引しないこと, 強い吸引力をかけない ことなどに心がけることが大切である。なお，葉ら6) は，腹水を有する卵巣癌患者 6 例を対象に腹水および 腹水を全量採取後の腹腔洗浄細胞診を比較し, 以下の ように報告している。すなわち，同時に施行した腹水 ならびに腹腔洗浄細胞診は, 全例に癌細胞が認められ たこと, 腹腔洗浄細胞診は, 癌細胞以外の細胞が少な いこと, 癌細胞集塊が少なく単離癌細胞の比率が高い こと, および癌細胞の細胞質や核所見の判定が容易で あることから，組織推定診断に有利である点を指摘 し, 腹水全量排液後の腹腔洗浄細胞診の有用性を強調 した。

卵巣癌の検出を目的とした腹腔細胞診は，ときにい くつかの疾患と細胞診断学的鑑別診断を要する。主要 なものは, (1) 異型中皮細胞増殖症 atypical mesotherial proliferation, (2) 強い炎症性変化, (3) mullerian inclusion, (4) 繊毛をもった卵管円柱上皮，(5) 子宮内膜症病巣加ら遊離した子宮内膜腺上皮，6) 卵 巣境界悪性表層上皮性・間質性腫瘍に随伴した体腔上 皮増殖症などである7). しかしながら，患者の年齢， 既往歴, 臨床所見, ガラス標本に出現する異型細胞の 量, 細胞集団構造 (腺, 腺管構造など), 核の異型性 などを勘案すれば，卵巣腺癌の細胞診断上の鑑別は必 ずしも困難ではない. 事実われわれの症例 $4,6,7$ は, 腹腔細胞診に多数の贯性腺癌細胞が出現し, それ らは摘出腫瘍の病理組織像によく一致するものであっ た.

腹腔細胞診に出現する異型細胞を卵巣腺癌と鑑別す るために，各種のモノクローナル抗体による免疫染色 法を利用する試みがなされているが8,9), 卵巣癌術後 管理の目的に行われる腹腔洗浄細胞診でそのような特 殊染色を要するものは多くないと考える.

\section{Summary}

The early detection of intraperitoneal recurrence in ovarian cancer patients has been achieved by serological assay of tumor markers or radiological (CT, MRI, USG) study. We tried a new follow up method for ovarian car- cinoma patients using serial peritoneal washing cytology from a subcutaneously implanted Infuse-A-Port.

Two cases of 7 showed no correlation between clinical findings (ascites, serological assay and radiological study) and peritoneal washing cytology. One case had no ascites, a normal serum CA-125 value and no evidence of disease on radiological study, but was found to have intraperitoneal dissemination of ovarian carcinoma on second look laparotomy. This case had malignant cells in the peritoneal cavity on peritoneal washing cytology before normal clinical findings. This suggests that serial peritoneal washing cytology has potential use in the follow up of ovarian cancer patients when the intraperitoneal port is implanted under the skin.

\section{文献}

1）大野正文・他：婦人科癌に対する $\mathrm{CBDCA}$ 腹腔内投与に おける薬理動態とその臨床効果, 癌と化学療法, 19 : 2356〜2361, 1992.

2) Sears, D., et al. : The cytologic diagnosis of malignant neoplasms in pleural and peritoneal effusions, Acta Cytol., 31: 85 97, 1987.

3) Graham, J.B., et al. : Preclinical detection of ovarian cancer, Cancer, 17:1414 1432, 1964.

4) Grillo, D., et al. : Early diagnosis of ovarian carcinoma by culdocentesis, Obstet. \& Gynecol., $28: 346$ $\sim 350,1966$.

5) Luesley, D.M., et al. : Prospective comparative cytologic study of direct peritoneal smears and lavage fluids in patients with epitherial ovarian cancer and benign gynecologic disease, Acta Cytol., 34 : 539 544, 1990.

6）葉 清泉・他：卵巣癌の細胞診 組織推定診断に対する 腹腔内洗浄細胞診の有用性について，日産婦誌，36:30 $\sim 36,1984$

7) Covell, J.L., et al. : Peritoneal washings in, ovarian tumors. Potential sources of error in cytologic diag. nosis, Acta Cytol., $29: 310 \sim 316,1985$.

8) Szpak, C.A., et al. : Detection of adeno-carcinoma in peritoneal washings by staining with monoclonal antibody B 72. 3., Acta Cytol., $33: 205 \sim 214,1989$.

9) Guzman, J., et al. : Maliganat ascites of serous papillary ovarian adenocarcinoma. An immunocytochemical study of the tumor cells, Acta Cytol., 32 : 519 522, 1988. 